\title{
ZÖMÍTÉS VÉGESELEMES MODELLEZÉSE A HŐFEJLŐDÉS FIGYELEMBE VÉTELÉVEL
}

\section{FINITE ELEMENT MODELING OF UPSETTING CONSIDERING HEAT GENERATION}

\author{
Mihalovits Roland ${ }^{1}$, Gonda Viktor ${ }^{2}$, Széll Károly ${ }^{3}$ \\ 1,2 Óbudai Egyetem, Bánki Donát Gépész és Biztonságtechnikai Mérnöki Kar, Anyag \\ és Gyártástudományi Intézet, 1081 Budapest, Népszínház u. 8. \\ ${ }^{3}$ Óbudai Egyetem, Alba Regia Müszaki Kar, 8000 Székesfehérvár, Budai út 45. \\ ${ }^{1}$ mihalovits.roland@gmail.com; ${ }^{2}$ gonda.viktor@bgk.uni-obuda.hu
}

\begin{abstract}
In this article, a finite element modeling of upsetting of a cylindrical workpiece is presented. In the modeling, the effect of friction, heat generation from the deformation, and the heat losses from conduction and convection are considered.
\end{abstract}

Keywords: finite element analysis, coupled model, friction, thermal balance.

\section{Összefoglalás}

A cikkben egy hengeres munkadarab zömítésének a végeselemes modellezését mutatjuk be a súrlódás, a képlékeny alakváltozásból adódó hőfejlődés, és az alakítás utáni hőelvezetés számításának figyelembe vételével.

Kulcsszavak: végeselemes analízis, csatolt modell, súrlódás, hőegyensúly.

\section{Bevezetés}

A végeselemes módszer (VEM) segítségével a képlékenyalakítás techno-lógiai tervezése nagyban egyszerüsíthető. A technológiai paraméterek számítása komplex alakítási eseteknél nagyon bonyolult képletek alkalmazását igényli, vagy nagyfokú egyszerüsítésekkel lehet csak becslést tenni, a mérésük nem megoldható, vagy költséges. A végeselemes módszer megoldást adhat ilyen esetekben, a szimulációk segítségével, virtuális prototipizálással a próbagyártás folyamata is lerövidíthető, így jelentős költség-megtakarítás érhető el. A modell segítségével az alakítás folyamatában vizsgálhatók a feszültségek, alakváltozások és egyéb ezekből számítható paraméterek változása, ezzel segítséget nyújtva a technológia optimalizálására [1].

A VEM egy numerikus módszer, amely segítségével a testek mechanikai és/vagy termikus modelljét nem folytonos kontinuumként, hanem részekre, ún. elemekre bontva alkotjuk meg. Ez a módszer a mai elérhető számítási kapacitás mellett jelentősen meggyorsítja a tervezések, és számítások idejét.

A végeselemes modellezéshez az MSC Marc Mentat 2016 programot használtuk, mely jól alkalmazható a képlékenyalakító technológiák termikus-mechanikus modellezésére [2]. 
Jelen cikkben egy hengeres test zömítésének végeselemes modellezését mutatjuk be, ahol a cél egyrészt egy mechanikaiképlékeny modell megalkotása, valamint ennek a csatolt hőtani kiterjesztése, a gyors alakváltozásból adódó hőfejlődés vizsgálata, valamint az alakítás utáni lehülés számítása. A zömítés modellezését több részletességi szintre bontjuk, a kezdeti súrlódásmentes képlékeny alapmodelltől egészen egy olyan modellig, amely alkalmas a hőtani vizsgálatok elvégzésére.

\section{A modell felépítése}

A vizsgált munkadarab egy Ø20 mm átmérőjü, és $30 \mathrm{~mm}$ magas acél henger. A modell megalkotása során csupán a geometria tengelymetszetének negyede került megrajzolásra a szimmetriát kihasználva, síkbeli tengelyszimmetrikus esetet tekintve. A szerszám átmérője $\varnothing 30 \mathrm{~mm}$, a magassága pedig $10 \mathrm{~mm}$. A zömítés során a mozgó szerszámelem elmozdulás-vezérelt, a mozgás lineáris, az alakításnál a bélyegút a munkadarab magasságának a harmada.

A modell komplexitását négy szintre bontottuk: az első szintű modell az ideális alakításhoz tartozik, a második szinten a súrlódást figyelembe vesszük, a harmadik szinten a hőfejlődést, a negyedik szinten a szerszám hővezetését.

A szerszám modellje az első szintü modellben merev, így ennek hálózására nincs szükség. A munkadarab rugalmasképlékeny keményedő anyagmodellt kap, így ez hálózott lesz. Az érintkezést súrlódásmentesnek tekintjük.

Miután elkészültek a geometriák, a következő lépés az anyag mechanikai tulajdonságainak megadása (1. táblázat), az érintkezések létrehozása, a terhelési eset, valamint a számítási feladat beállítása. A szimuláció sikeres futásával az alapmodell megfelelőnek mondható, az alap modell alkalmas a fő alkotóelemek helyességének, valamint a számítási feladat lefutásának ellenőrzésére.

A második modellezési szint a súrlódás figyelembe vétele. Nem csupán a súrlódási együttható értékét kell rögzítenünk, hanem a súrlódás típusát is, ebben a modellben Kudo-féle súrlódást alkalmaztunk. A Kudoféle súrlódási számot a munkadarab és a szerszám között $m=0,8$ értékkel definiáltuk.

A harmadik modellezési szint a gyors alakváltozásból adódó hőfejlődés vizsgálata. Ehhez definiálni kellett a munkadarab hőtani jellemzőit: a hővezetési tényezőt, a fajlagos hőkapacitást (fajhő), és a kezdeti hőmérsékletet, amelynek értéke 293 K. A további termikus, illetve mechanikai paramétereket az 1. táblázat tartalmazza. Ezek mellett aktiválni kellett a képlékeny alakváltozásból adódó hőfejlődési csatolt modell használatát.

1. táblázat. A termikus- és mechanikai paraméterek

\begin{tabular}{|c|c|c|}
\hline Jellemző & Munkadarab & Szerszám \\
\hline Rugalmassági modulus [GPa] & 200 & - \\
\hline Poisson-tényező [-] & 0.3 & - \\
\hline Folyáshatár [MPa] & 275 & - \\
\hline Keményedési együttható [MPa] & 722 & - \\
\hline Keményedési kitevő [-] & 0,262 & - \\
\hline Sürüség $\left[\mathrm{kg} / \mathrm{m}^{3}\right]$ & \multicolumn{2}{|c|}{7800} \\
\hline Hővezetési tényező $\left[\frac{W}{m \cdot K}\right]$ & 36 & 40 \\
\hline Hőkapacitás $\left[\frac{J}{m^{2} \cdot K}\right]$ & 450 & 350 \\
\hline $\begin{array}{l}\text { Hőátadási tényező }\left[\frac{W}{m^{2} \cdot K}\right] \\
\text { (környezet és modell között) }\end{array}$ & \multicolumn{2}{|c|}{2,95} \\
\hline $\begin{array}{c}\text { Hőátadási tényező }\left[\frac{W}{m^{2} \cdot K}\right] \\
\text { (munkadarab és szerszám } \\
\text { között) }\end{array}$ & \multicolumn{2}{|c|}{400} \\
\hline
\end{tabular}


A negyedik modellezési szinten a szerszám hővezetése is beépítésre kerül, így a müvelet során és után kialakuló hőegyensúly változása vizsgálható. Ezért ebben az esetben már hálózott szerszámra van szükség, hiszen a program csak csomópontokra tudja számítani a különböző paramétereket, tehát a hőmérsékletet is, viszont mechanikai szempontból merevnek tekintjük a szerszámot, így ennek merev-hálózott modellje lesz. Definiáltuk az érintkezéseknél a munkadarab-, valamint a szerszám és a környezet közötti hőátadási tényezőt is, amelyek értékét szintén az 1. táblázat tartalmazza. A már meglévő modellek módosításánál, kiegészítésénél nagyon körültekintően kell eljárni, hiszen az egymással érintkező elemek átfedő csomópontjainál könnyen torzíthatjuk a teljes modellt, hiszen a modellalkotás után törölni kell az duplikált csomópontokat és elemeket.

\section{Eredmények}

A különböző modellezési szintek eredményeit külön-külön mutatjuk be. Az első szintü alapmodell célja a helyes lefutás ellenőrzése, ezért az most nem kerül részletezésre.

\section{1. A súrlódás hatása}

A súrlódás hatása a munkadarab hordósodásában jelenik meg, amelyet az 1. ábra szemléltet. Az ábrán a szimmetria tengelye a vízszintes tengely, a munkadarab szerszámmal érintkező felülete a bal oldali függőleges vonal ebben a metszetben, a jobb oldali vonal a tükörszimmetria síkját jelöli.

A hordósodás azzal magyarázható, hogy a munkadarab és a szerszám érintkező felületén a megjelenő súrlódó erő gátolja az elmozdulást sugár irányban, így ezen a részen a munkadarab átmérő növekedése a zömítés során kisebb lesz. Ahogy távolodunk tengelyirányban a szerszámtól, úgy csökken ennek a jelenségnek a hatása.

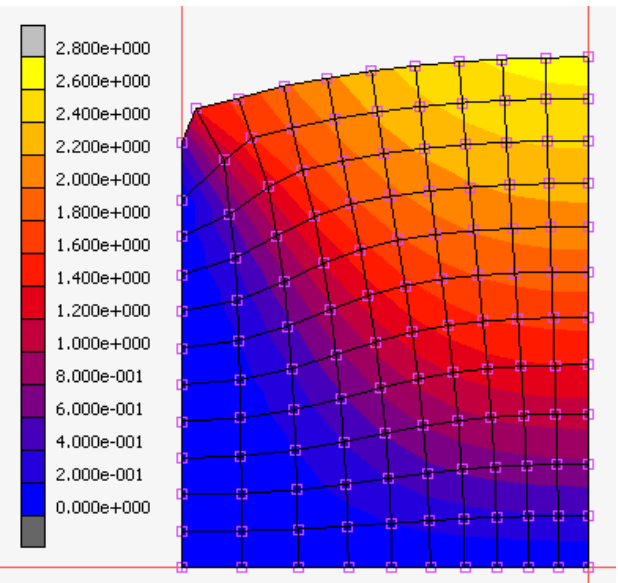

1. ábra. A hordósodás jelensége $(m=0,8)$. A skála a radiális eltolódást mutatja $\mathrm{mm}$ ben.

A súrlódási együttható értékének növelése nem minden esetben eredményez nagyobb sugár irányú méretnövekedést.

Ahogy az 1. ábrán is látható, a nagy együttható azt eredményezi, hogy a paláston az első elem nagyon nagy torzulást szenved, itt megfigyelhető egy jelentős ugrás a hordósodás ívében. Ezt sürübb hálózással ki lehet küszöbölni, hogy pontosabb eredményt kapjunk.

\subsection{Hőfejlődés}

Az alakítás hatására hő fejlődik a munkadarabban. Ha az alakítás kellően gyors, jelen esetben 0,5 másodperc, akkor a hőveszteség elhanyagolásával az adiabatikus eset vizsgálható. A munkadarab hőmérséklete emelkedik, a hőmérséklet eloszlása nem homogén, ahogy az a 2. ábrán megfigyelhető. A legmagasabb hőmérséklet a munkadarab középpontjában adódik, amíg a legalacsonyabb hőmérséklet a munkadarab tengelyének a szerszám síkját metsző pontjában, itt a súrlódásnak nincs jelentős hatása. Az alakváltozás hatására létrejövő legnagyobb hőmérséklet 380 Kelvin, amely 87 Kelvinnel nagyobb, mint a kezdeti szobahőmérséklet. 


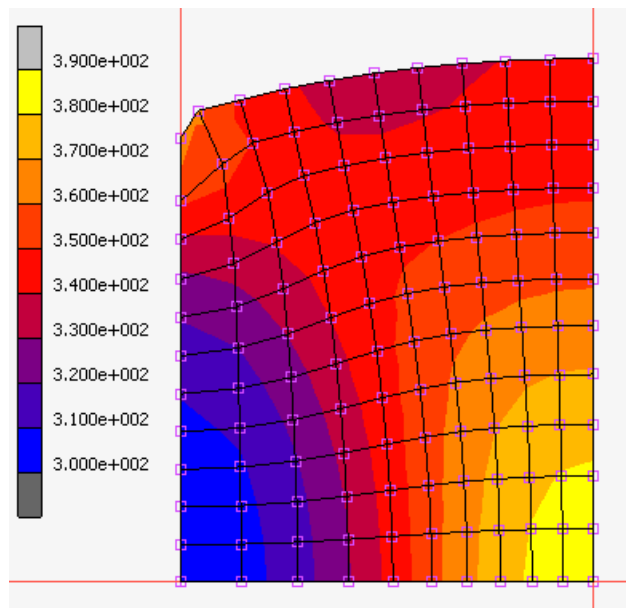

2. ábra. A hömérséklet eloszlása a zömités végén

\subsection{Hőveszteség}

A hőegyensúlyt azért érdemes vizsgálni az alakítás végéhez tartozó bélyeghelyzet megtartása mellett, így a szerszám hővezetésének a hatását meg lehet mutatni.

Az eredmények kiértékeléséhez különböző időpillanatokban $(\mathrm{t}=\{0,5 ; 1,82$; $10,26 ; 43,46 ; 100,5\}$ s) felvettem a munkadarab tengelyvonalán a hőmérsékletet a szerszám felső síkjától a munkadarab félmagasságáig.

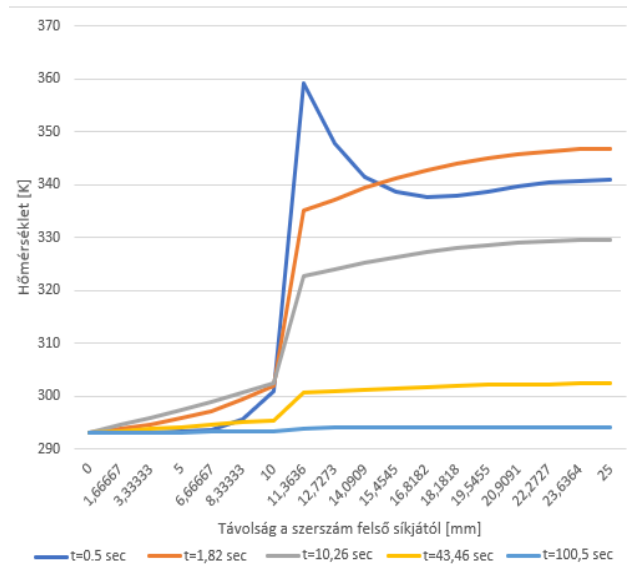

3. ábra. A hömérséklet alakulása szerszám felsö síkjától a munkadarab félmagasságáig
Az így kapott eredményeket a 3. ábrán látható grafikonban egyesítettem, amelyen megfigyelhetjük, hogy az alakítás végén ( $\mathrm{t}=0,5 \mathrm{~s})$ a szerszám és a munkadarab érintkezési síkjának közelében a legmagasabb a hőmérséklet, hiszen itt volt az egyik legnagyobb alakváltozás. Ezután a véghelyzetben tartás során ebből az első csomópontból a hőmérséklet elkezdett terjedni mindkét irányba, hiszen ennek a csomópontnak a hőmérséklete csökkent, míg a szerszám, illetve a szomszédos csomópontok hőmérséklete is emelkedett, ez a jelenség figyelhetö meg a $(\mathrm{t}=1,82 \mathrm{sec})$ időpillanatban.

Ezután a munkadarab és a szerszám ezt a hőeloszlási karakterisztikát megtartva hülnek vissza a kezdeti hőmérséklete $100 \mathrm{~s}$ elteltével.

\section{4. Összegzés}

A kutatás során elkészült a zömítés végeselemes modellje, négy különböző részletességi szinttel, amelynek segítségével meg lehetett vizsgálni a súrlódás hatását, a gyors alakváltozásból adódó hőfejlődést, valamint a keletkezett hő elvezetését.

\section{Köszönetnyilvánítás}

A szerzők köszönetüket fejezik ki az Emberi Erőforrások Minisztériuma ÚNKP17-I-OE-779/15 pályázati támogatásának, valamint az EFOP-3.6.1-16-2016-00010 pályázati támogatásnak.

\section{Szakirodalmi hivatkozások}

[1] Henry S. Valberg: Applied Metal Forming, Chapter 11., Cambridge, 2010.

[2] Marc E: Demonstration Problems, Chapter 8.59; Volume MSc Software, 2013. 